\title{
Forum
}

\section{Hunting the world's wildlife to extinction}

\author{
Elizabeth L. Bennett, E. J. Milner-Gulland, Mohamed Bakarr, Heather E. Eves, John G. Robinson and \\ David S. Wilkie
}

The twin threats to wildlife across the world are habitat loss and hunting, but the perception of which looms larger has fluctuated over time. In the last 10 years, however, we have come to realize that hunting is the major threat across the tropics. Ironically, given the success we have had in protecting certain key areas, these areas are increasingly becoming 'empty forests' (Redford, 1992). The threat posed by hunting is especially great in tropical forests, where the productivity of edible wildlife is extremely low. Certain groups of species are especially vulnerable to hunting (e.g. McGowan \& Garson, Guest Editorial, this volume), but the current scale of hunting affects the whole biotic community. Using conservative estimates of offtake about 28 million bay duikers, 16 million blue duikers and more than 7 million red colobus are taken from the forests of Central Africa every year (Wilkie \& Carpenter, 1999; Fa \& Peres, 2001). Extraction of wildlife from such forests is presently six times the sustainable rate (Bennett, 2002).

To assess the current state of knowledge and identify areas for action two related symposia, on hunting and the conservation of exploited species, were held at the 16th Annual Meeting of the Society for Conservation Biology at the University of Kent, Canterbury, UK, in July 2002. In addition to data on the scale of the problem, the symposia included case studies of approaches that are starting to succeed. These symposia attracted a large audience and stimulated vibrant discussions. This issue of Oryx contains Forum pieces arising out of this debate.

Elizabeth L. Bennett (Corresponding author) and John G. Robinson Wildlife Conservation Society, 2300 Southern Blvd., Bronx, New York 10460, USA. E-mail: liz@lizbennett.org

\section{E. J. Milner-Gulland Renewable Resources Assessment Group, Department of Environmental Science and Technology, Royal School of Mines, Imperial College London, Prince Consort Road, London, SW7 2BP, UK.}

Mohamed Bakarr Center for Applied Biodiversity Science, Conservation International, 1919 M Street N.W., Suite 600, Washington, DC 20036 , USA.

Heather E. Eves Bushmeat Crisis Task Force, 8403 Colesville Road, Suite 710, Silver Spring, MD 20910, USA

David S. Wilkie Wildlife Conservation Society, 18 Clark Lane, Waltham, MA 02451-1823, USA.

Manuscript accepted for publication 6 August 2002.
Actions to address the problems are proceeding apace across the tropical world. More effective enforcement of protected areas, partnerships with logging companies in Congo, and bans on wildlife trade in Sarawak are all proving successful. However to make the leap from action at a local level to action across the political and development arena we need more information. It is clear that levels of offtake from tall forests are grossly unsustainable (Robinson \& Bennett, 2000), and inadequate to support even subsistence consumption by growing rural human populations, let alone a commercial market. But forest edges may be more productive (Barnes, 2002), and harvests of rodents and other edge species are possibly sustainable in some areas. How hunting can be managed so that productive species can be harvested whilst not hampering efforts to conserve the more vulnerable species is unclear even in theory, let alone in practice. We know that many people, be they hunters, traders or consumers, depend on the harvest of wildlife, but we have contradictory data on what proportion of the harvest is consumed in rural communities, and how much enters urban markets. We do not have a good understanding of how a decline in harvest rates will affect people's protein consumption or what would be the economic impact of strict control of the commercial trade. There are no clear data on the ecological effects caused by the large volume of unsustainable wildlife trade. There is not yet consensus on the extent to which wildlife consumption is affected by price, especially relative to domestic alternatives, nor on the complex interactions of the driving forces behind the commercial trade.

The answers to these questions will determine conservation actions. While there is a broad recognition that there is a serious conservation problem, conservation programmes have been hampered in their design and implementation by the outstanding questions. The answers are not obvious (c.f. Ling et al., this volume), and while continuing our efforts on the ground, we must simultaneously step up our efforts, combining biological understanding (Rowcliffe, this volume) with expertise from other disciplines (Robinson \& Bennett, this volume). We must turn scientific knowledge into much more widescale action through open discussion of the success and failures of different approaches, and disseminate the information much more efficaciously to governments 
and the development and private sectors. Moreover, we need to apply our scientific understanding much more effectively to influencing policies that undermine potential mitigation efforts. Only then will we be able to determine how best to prevent wildlife across the tropics from being hunted to oblivion, with all of its implications for both biodiversity and human communities.

\section{References}

Barnes, R.F.W. (2002) The bushmeat boom and bust in West and Central Africa. Oryx, 36, 236-242.
Bennett, E.L. (2002) Is there a link between wild meat and food security? Conservation Biology, 16, 590-592.

Fa, J.E. \& Peres, C. (2001) Hunting in tropical forests. In Conservation of Exploited Species (eds J.D. Reynolds,

G.M. Mace, K.H. Redford \& J.G. Robinson), pp. 203-241. Cambridge University Press, Cambridge, UK.

Redford, K.H. (1992) The empty forest. Bioscience, 42, 412-422.

Robinson, J.G. \& Bennett, E.L. (2000) Carrying capacity limits to sustainable hunting in tropical forests. In Hunting for Sustainability in Tropical Forests (eds J.G. Robinson \& E.L. Bennett), pp. 13-30. Columbia University Press, New York, USA.

Wilkie, D.S. \& Carpenter, J.F. (1999) Bushmeat hunting in the Congo Basin: an assessment of impacts and options for mitigation. Biodiversity and Conservation, 8, 927-955. 